\title{
ADVERSE CLAIM DOCTRINE: ITS RELATION TO STOP PAYMENT PROTECTION
}

Stopping payment on his check is the most common source of comfort to a depositor who finds or fears that he has been cheated in a business deal. ${ }^{1}$ However, should he lose in the "race of diligence" through failure to get a proper stop order to the drawee bank before it has paid or certified the check, he may find little help in the stop payment remedy. ${ }^{2}$

This comment will discuss the circumstances under which additional protection may be available to the drawer when the drawee bank retains possession of funds, after payment or after certification, which might be available to secure his claim.

\section{I}

The basic common law rules as to stop payment by the drawer of an ordinary check are: (1) that the right is absolute- the drawer may protect his status quo ante by revoking his order to his bank for any reason he chooses; ${ }^{3}(2)$ that the stop order destroys any authority in the bank to make payment on the check when it is presented; thus, that if the bank mistakenly pays over a stop order it may not charge the drawer's account, ${ }^{4}$ defenses of due care or good faith not being relevant; (3) that the stop order is a permanent revocation of authority as to the check in question; 5 and (4) that to have effect the stop order must be received before the bank has paid or certified the check. ${ }^{6}$

The stop payment right is considered to be created by an implied term in the contract of deposit. ${ }^{7}$ Payment or certification is said to terminate the protection it affords because each individual transaction under the deposit contract is irrevocably performed when the bank, acting under the authority of a drawer's

${ }^{1}$ A recent comment in this Review discussed the traditional rules of stop payment and current attempts to change them, concluding that stop payment is a sufficiently important service to bank depositors that the banks' absolute common law duty to honor stop orders should not be watered down by statutory authorization of exculpatory clauses. Stop Payment: An Ailing Service to the Business Community, 20 Univ. Chi. L. Rev. 667 (1953).

2 Ibid., at 670-71 n. 14.

${ }^{3}$ See note 9 infra.

4 See, e.g., Florence Mining Co. v. Brown, 124 U.S. 385, 391 (1888). Cases stating the rule representing twenty-four states are collected in 5A Michie, Banks and Banking $\$ 193$ n. 45 (rev. ed., 1950).

'Hiroshima v. Bank of Italy, 78 Cal. App. 362, 248 Pac. 947 (1926). See also Universal Supply Co. v. Hildreth, 287 Mass. 538, 192 N.E. 23 (1934); Thompson v. Killheffer, 99 N.J.L. 439, 125 Atl. 11 (Ct. of E. and A., 1924), rev'g 98 N.J.L. 359, 119 Atl. 770 (S. Ct., 1923); Young v. Hembree, 181 Okla. 202, 73 Pac. $2 d 393$ (1937); Bluefield Nat. Bank v. Picklesimer, 102 W. Va. 128, 135 S.E. 257 (1926).

'See note 4 supra.

'For detailed analysis of this logic, see Moore et al., Legal and Institutional Methods Applied to Orders to Stop Payment of Checks-I. Legal Method, 42 Yale I.J. 817 (1933). 
order of which it has no notice of revocation, makes payment or assumes the new liabilities of a contract of certification. ${ }^{8}$

However, the basic policy reasons underlying the stop payment right do not cease to have force on either of these two occurrences. It has been suggested that the policy supporting the stop payment duty is that, once the check is given, the drawee bank is the only agency whose diligence can prevent possible loss to the drawer, and reduce the probability of incurring the social costs of resort to litigation. ${ }^{9}$ But a bank may be able to forestall such injuries and costs as long as it retains physical control of the funds, which it may be said to do after certification and after payment in those cases where the payee deposits the proceeds or. uses them to purchase an obligation of the bank as yet undischarged. In these circumstances funds could be held back sufficient to secure the drawer from possible loss pending some steps toward settlement of his claim, although perhaps not without risk of liability. But how far have the courts gone in requiring or permitting such protection to be extended?

II

The "adverse claim" cases in some respects take up where the stop payment cases leave off. These cases are based upon the common law rule that a bank having "reasonable notice of a bona fide claim that money deposited with it is the property of another than the depositor"10 is under some duty to the claimant not to permit withdrawals which deplete the deposit to below the amount to which claim is made. ${ }^{11}$

This principle of duty to a proper adverse claimant is extended to a great variety of situations. An important group are those cases where funds (including, of course, a check) are wrongfully deposited-where the money has been misappropriated or obtained in an illegal or voidable transaction, ${ }^{12}$ or where the

${ }^{8}$ See cases cited in Brannan, Negotiable Instruments Law $\$ 189$, at $1316-19$ (7th ed., Beutel, 1948).

20 Univ. Chi. I. Rev., op. cit. supra note 1, at 668 .

${ }^{10}$ Miller v. Bank of Washington, 178 N.C. 152, 96 S.E. 977 (1918).

${ }^{11}$ The general rule is discussed and cases cited in 2 Paton, Dig. Leg. Ops. 1, 656-59 (1942); 5A Michie, Banks and Banking $\$ 82$ (1950); 5 Zollman, Banks and Banking $\S 3198$ (1936); 1 Morse, Banks and Banking \$\$ 342-46 (6th ed., 1928); Tiffany, Banks and Banking 49-50 (1912); 1 Bolles, Modern Law of Banking 481 (1907); Hart, The Law of Banking 231-32 (2d ed., 1906); Zane, Banks and Banking \$ 134 (1900). See also Conflicting Rights, Duties and Liabilities of Interested Parties Upon Assertion of Adverse Claims to Bank Deposits, 51 Yale L.J. 986 (1942).

The rule has been modified by statute in twenty-two states, largely as a result of activities of the American Bankers' Association in promoting a uniform Adverse Claim to Bank Deposit Statute. Under the American Bankers' Association statute notice of an adverse claim creates no duty in the bank until and unless the claimant obtains a court order restraining payment of the deposit, or furnishes an indemnity bond. Although the statutes as enacted vary in form, the central objectives' are the same as that of the Association's recommendation. For citation to the state acts, see 2 Paton, Dig. Leg. Ops. 1, 657 (1942), and Supplement, "Deposits" \$6 (1950).

$12 \mathrm{It}$ is this group which includes the cases most like those in which stop payment orders are typically given; these will be discussed below. In addition, it includes embezzlement, 
deposit itself is a misappropriation..$^{13}$ Another type of case involves money deposited lawfully by a fiduciary where the adverse claimant asserts himself to be the beneficial owner and that the fiduciary relationship has been revoked or limited, ${ }^{14}$ perhaps by action of law, ${ }^{15}$ or that the deposit is not properly subject to garnishment or attachment, ${ }^{16}$ general assignment, ${ }^{17}$ or distribution after death ${ }^{18}$ as property of the nominal depositor.

The common element in so varied an array of fact situations is that in each the claimant alleges that the depositor is without proper "title" to the funds, or that his title is subject to a superior equitable interest. ${ }^{19}$ It seems to be the essence of a proper adverse claim that it is a claim to the specific sum on deposit, and that the monies to which original ownership is asserted, therefore, be traceable to the deposit. ${ }^{20}$ Thus, no adverse claim will be allowed for purposes of se-

stolen money, and forged check cases: Emigrant Industrial Savings Bank v. Foye, 117 N.Y. Misc. 706, 192 N.Y. Supp. 898 (S. Ct., 1922) (stolen goods sold and money deposited to account opened by thief under an "alias"; adverse claimant succeeds in tracing); First State Bank \& Trust Co. v. First Nat. Bank of Canton, 314 Ill. 269, 145 N.E. 382 (1924) (notice of a forgery of a check operates to invoke adverse claim rules as between claimant, depositorforger, and depository bank); cases in which cash is obtained in fraudulent or illegal transactions: First Nat. Bank of Wellsborough v. Bache, $71 \mathrm{~Pa} .213$ (1872) (funds acquired by wrongful sale of another's property); Phillips v. Suffolk Savings Bank, 219 Mass. 597, 107 N.E. 401 (1914) (wife deposited husband's funds, without his concent, to her account); and cases involving deposits of funds obtained in any breach of a fiduciary duty where a constructive trust might be imposed upon the funds. Consult 3 Bogert, Trusts and Trustees, c. 24 (1946).

13 These are usually cases where statute prohibits deposit of public funds except in designated depositories or specifies the conditions under which such deposits may be made. Brogan v. Kreipe, 116 Kan. 506, 227 Pac. 261 (1924); Marquette Fire \& Water Commissioners v. Wilkinson, 119 Mich. 655, 78 N.W. 893 (1899).

14 France Milling Co. v. First Nat. Bank of Cobleskill, 138 App. Div. 645, 122 N.Y. Supp. 736 (3d Dep't, 1910) (agency of nominal depositor revoked); Arnold v. Sedalia Nat. Bank, 100 Mo. App. 474, 74 S.W. 1038 (1903) (scope of agency limited to require principal's consent in each transaction).

${ }^{15}$ In re Interborough Consolidated Corp., 267 Fed. 914 (S.D. N.Y., 1920).

${ }^{16}$ Levin v. Lerner, 290 Mass. 294, 195 N.E. 387 (1935) (true owner enters adverse claim to protect funds from attachment by creditor of nominal depositor); Cantonzaro \& Sons v. Hellman Commercial Trust \& Savings Bank, 281 Pa. 468, 126 Atl. 812 (1924) (holder of checks drawn on fund, endorsed by equitable owner, enters adverse claim as against attachment by creditor of nominal depositor).

17 Webb v. Newhall, $274 \mathrm{~Pa} .135,117$ Atl. 793 (1922).

${ }^{18}$ First Nat. Bank of Portland v. Reynolds, 127 Me. 340, 143 Atl. 266 (1928); Bruff v. Rochester Trust \& Safe Deposit Co., 118 Misc. 394, 193 N.Y. Supp. 321 (S. Ct., 1922).

19 The general rule, of course, is that a bank impliedly contracts to return any general deposit on demand, and is prohibited from asserting for its own benefit any adverse title to defeat the nominal depositor's right to withdraw or draw checks. Thus, when it has no notice from an adverse claimant, it cannot refuse a depositor's order. Gibralter Realty Corp. v. Mount Vernon Trust Co., 276 N.Y. 353, 12 N.E. 2d 438 (1938). And see 5A Michie, Banks and Banking $\$ 99$ (rev. ed., 1950). But, it is said that "the presumption of ownership in the depositor is rebuttable and yields to competent evidence of ownership in another." 5 Zollman, Banks and Banking \& 3198, at 224 (1936).

${ }^{20}$ See Emigrant Industrial Savings Bank v. Foye, 117 N.Y. Misc. 706, 192 N.Y. Supp. 898 (S. Ct., 1922); Peter Adams Co. v. Nat. Shoe \& Leather Bank, 9 N.Y. Supp. 75 (S. Ct., 1887). 
curing payment of an unrelated debt owed by the depositor. ${ }^{21}$ In all cases which qualify, the principles applied in defining the duties of the depository bank and the claimant are the same.

In the earliest American adverse claim case involving a stop payment type of situation, Peter Adams Company v. National Shoe \& Leather Bank, ${ }^{22}$ the plaintiffclaimant had given its check in partial performance of a fraudulent contract into which it had entered relying upon misrepresentations of the payee as to his authority to close a deal, and upon a forged note. The check was deposited to the defrauder's account in defendant bank, and the ruse was not discovered until the check had been paid by the drawee, too late for an ordinary stop order. The plaintiff-claimant at once served notice on the depositor "disaffirming and rescinding the agreements with him," ${ }^{23}$ and notice of the claim was given to the depository bank, which, however, subsequently allowed further payments from the account. The bank's defense, that an attachment had been made of the funds in favor of the person to whom the payment was made, was held invalid, "for, as [the attachment] was issued against [the depositor] alone, no more could be seized under it than his right or interest in the money in controversy, and that was subordinate to the legal right of the plaintiff to reclaim it upon the discovery of the fraud and forgery, and the election to rescind their agreement. ... [I]t had the right to disaffirm its transactions ... and follow the money and reclaim it, so far as its identity could be traced. . .."24

The importance of plaintiff's acts of rescision was made clear in Barnard 0. First National Bank of Newpoint, ${ }^{25}$ where the defrauder deposited the proceeds of a phoney stock sale in defendant bank and later withdrew the sum partly in cash and partly in the form of a certified check. Plaintiff notified the bank of his claim and the faudulent acts, requesting that the certified check not be honored. The court rejected the defense that certification of the check immunized the deposit from the adverse claim, but found for defendant bank because plaintiff had not, "before or at the time of the notice relied upon," scind the transaction and return the worthless share certificates. The deal was not "void" but "voidable." The court implied that a "void" transaction would not require the notice to include a recital of acts of rescision.

One of the cases there distinguished as involving a "void" transaction was Drumm-Flato Commission Company v. Gerlach Bank, ${ }^{27}$ in which the money in question was given in return for livestock subject to a mortgage owned by plaintiff, and had been deposited to the credit of the vendor's account in defendant

${ }^{21}$ See Hastings v. First Nat. Bank of Corning, 170 Ark. 939, 281 S.W. 905 (1926).

29 N.Y. Supp. 75 (S. Ct., 1887).

23 Ibid., at 76.

24 Ibid., at 77 .

2561 Ind. App. 634, 111 N.E. 451 (1916).

${ }^{26}$ Ibid., at 635 and 452

27107 Mo. App. 426, 81 S.W. 503 (1904). 
bank. When the existence of the mortgage was discovered, a third party-another commission agent who had carried out the sale-notified the bank of the adverse claim. Nonetheless, ten days later, no legal process having been instituted, the funds were allowed to be withdrawn. The court reversed the judgment for defendant, finding that notice of an adverse claim by one other than the claimant may be adequate. Commenting upon this case, the Barnard court noted that "the party who sold the cattle had no title either to the cattle or the proceeds. It was therefore a void sale."28

The most recent important case, surprisingly unnoticed, is Gendler v. Sibley State Bank.29 In a legitimate business transaction, the buyer-plaintiff had by mistake made a $\$ 7,106$ overpayment to the defendant bank's depositor. The check was indorsed and deposited, and in the three weeks intervening before the plaintiff discovered the error and notified the bank of his adverse claim, all but $\$ 1,155.04$ of the depositor's account had been paid out. On receiving the notice the bank requested that the depositor draw a check for $\$ 1,100$, which he did, and for which the bank issued, but held, a cashier's check in that amount payable to the depositor. Six days after receiving the adverse claim notice, the bank, after a demand by the depositor and on the advice of its lawyer that it could not legally withhold the $\$ 1,100$, released the check to the depositor. Nearly eleven months later the buyer brought action against the bank and the depositor for the $\$ 7,106$ overpayment. The court found the bank not liable even for the $\$ 1,100$, discussing in detail the theory of an adverse claim case.

The liability of the bank, it held, must be in tort-based on a violation of the duty of the bank after notice "to withhold payment until the third party claimant can institute the necessary court proceedings to stop payment to the depositor by court order or process." 30 The duty is only "not to release the deposit unreasonably early after such third party makes known his adverse claim." 31 Thus to sustain a successful cause of action the adverse claimant will have the burden of proving: (1) that after giving notice he "diligently and promptly" instituted legal proceedings to tie up the account "by court process or order"; ${ }^{32}$ (2) that the depository bank had made an unreasonably early release of the deposit; and (3) that this breach of duty was the proximate cause of the loss. Plaintiff failed because he had not shown diligent and prompt proceeding. Thus, the case must be read to hold that six days may be an adequate period to respect the adverse claim..$^{33}$

The reason for the strictness of dilligence to which the claimant is held is clear.

${ }_{28} 61$ Ind. App. 634, 638, 111 N.E. 451, 452 (1916).

2962 F. Supp. 805 (N.D. Iowa, 1945).

${ }^{30}$ Ibid., at 813.

3! Ibid.

s2 Tbid., at 814 .

${ }^{33}$ In an earlier case involving the claim of a wife to funds deposited to his account by her husband, it was similarly held that the bank, which released the funds nine days after receipt of the notice, had allowed "reasonable time" for legal process to be instituted; the restraining order was secured on the tenth day, after payment had been made on the day preceding. Huff v. Oklahoma State Bank, 87 Okla. 7, 207 Pac. 963 (1922). 
Time may be of essential importance in commercial transactions handled by check. Great damage may be done to a depositor in having his account at least partially "frozen" for even a short period. And because of considerable imperfection in legal treatment of the problem of slander of credit, it is also important to banks that the "reasonable" period be a short one. The right of the nominal depositor to withdraw the funds in an account in his name at any time is an explicit or implied term of the contract of deposit. Thus, failure by the bank to honor checks properly presented may subject it to liability for slander of credit or breach of contract. ${ }^{34}$ On the other hand, permitting funds to be withdrawn in the face of an adverse claim later shown to be valid may also result in liability. So in self-protection the bank must assume the risk of determining or guessing whether the claim will be held valid, ${ }^{35}$ or at least in good faith. ${ }^{36}$ If its guess is correct, it is safe; ${ }^{37}$ but the duty to an adverse claimant does not immunize it from risk of liability to its depositor for breach of contract or slander of credit. On the contrary, the few cases which deal with the problem indicate that it may be liable if the claim should subsequently be held invalid..$^{38}$ In thus being forced into its own determination of validity in self-defense, the bank is forced into a highly perilous position involving risk of double payment, or an even greater liability if damage to business reputation can be shown by the depositor. ${ }^{29}$

These cases show that the bank's major protection under the common law, other than a correct guess as to the validity of the claim, was freedom from liability to the adverse claimant after withholding the funds for a "reasonable"

84 Thomas v. American Trust Co., 208 N.C. 653, 182 S.E. 136 (1935) (damages allowed on breach of contract theory); Schaffner v. Ehrman, 139 Ill. 109, 28 N.E. 917 (1891) ("legal malice" found and tort damages available); McFall v. First Nat. Bank of Forrest City, 138 Ark. 370, 211 S.W. 919 (1919) (presumption of substantial damages arises where depositor is engaged in commercial transactions). See also Nealis v. Industrial Bank of Commerce, 107 N.Y.S. 2d 264 (S. Ct., 1951).

${ }^{25}$ See, e.g., Miller v. Bank of Washington, 176 N.C. 152, 96 S.E. 977 (1918); 1 Morse, Banks and Banking $\$ 342$ (6th ed., 1926).

3 Ford v. Ames Nat. Bank, 196 Iowa 958, 195 N.W. 742 (1923).

${ }^{37}$ If the claim is in fact good, the bank cannot be held liable by the depositor. First State Bank \& Trust Co. v. First Nat. Bank of Canton, 314 Ill. 209, 145 N.E. 382 (1924). See France Milling Co. v. First Nat. Bank of Cobleskill, 138 App. Div. 645, 122 N.Y.S. 736 (3d Dep't, 1910); 5 Zollman, Banks and Banking $\$ 3198$, at 227 (1936).

${ }^{38}$ Pascagoula Nat. Bank v. Eberlein, 161 Miss. 337, 131 So. 812 (1931). Wildenberger v. Ridgewood Nat. Bank, 230 N.Y. 425, 130 N.E. 600 (1921) arose upon suit by a merchant depositor for injury to his credit resulting from the dishonoring of several checks during a period when his wife was advancing an adverse claim to one-half the account. Later the claim was withdrawn. In an opinion by Judge Cardozo the court reversed a ruling for the defendant, finding the bank's dishonor to be "with full knowledge of the state of the account, setting one risk against another, the risk of adverse claims against the risk of broken contracts." Ibid., at 428 and 600 . This decision seems clearly to place the bank in the position of being forced to judge the substantiality of the claim, with liability for a wrong guess.

${ }^{39}$ Depositor is aided by the presumption that substantial damage results if he is a businessman. Nealis v. Industrial Bank of Commerce, 107 N.Y.S. 2d 265 (S. Ct., 1951); Wildenberger v. Ridgewood Nat. Bank, 230 N.Y. 425, 130 N.E. 600 (1921); McFall v. First Nat. Bank of Forrest City, 138 Ark. 370, 211 S.W. 919 (1919). 
period. But what is a reasonable time in any situation is a question for a jury determination, ${ }^{40}$ not a satisfying standard when risk of heavy liability attends an error in judgment in either direction. 11

The other protection accorded the bank is provided by narrow judicial definition of a proper notice or a proper subject of an adverse claim. The cases are clear that the bank will owe the drawer-claimant no duty after payment of the check unless his situation falls within certain categories. If the underlying transaction is such that a court might be persuaded to call it "void" on its face, his position is strongest. But if the transaction is "voidable," as for fraud or some kinds of illegality, the courts appear to require steps for rescision before the

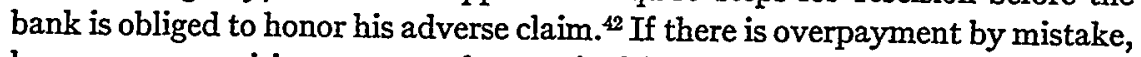
however, no rescision seems to be required. ${ }^{43}$ Lesser business reasons for stop orders, including failure of consideration in the underlying obligation, appear to provide no bases for an adverse claim duty.

Nor will a duty arise unless the notice is "adequate." Some cases, like Peter Adams Co., ${ }^{44}$ appear to require inclusion in the notice of a full statement of the basis of the claim, including recital of the acts of rescision, and formal tracing of the funds. Others indicate that notice may be effective though informal and incomplete, or will infer notice from the bank's supposed omniscience about a depositor's account. ${ }^{45}$ In no cases have the courts decided whether a typical stop order, received too late, might still serve as notice of an adverse claim. ${ }^{46}$ But

\footnotetext{
${ }^{10}$ Drumm-Flato Comm'n Co. v. Gerlach Bank, 107 Mo. App. 426, 432, 81 S.W. 503, 505 (1904); Huff v. Oklahoma State Bank, 87 Okla. 7, 8, 207 Pac. 963, 964 (1922).

11 This state of the case law is a reason for the active American Bankers' Association sponsorship of state legislation discussed note 11 supra. Consult 2 Paton, Dig. Leg. Ops.
1,657 (1942).
}

42 Consult discussion, page 138 supra. See also Wainwright v. Marine Nat. Bank, 72 Pa. Super. 221 (1919), which seems to indicate that not only notice, but "demand" for return of the funds, is required. But cf. Gibralter Realty Corp. v. Mount Vernon Trust Co., 276 N.Y. 353, 12 N.E. 2d 438 (1938).

${ }^{13}$ Consult discussion, page 139 supra.

"Consult discussion at note 22 supra.

is If the bank knows of the wrong directly or through other sources, a defect in the content of the notice of adverse claim may be cured. Peter Adams Co. v. Nat. Shoe \& Leather Bank, 9 N.Y. Supp. 75 (S. Ct., 1887) (bank secured further information through conversation with the drawer); McIntosh v. Detroit Savings Bank, 247 Mich. 10, 225 N.W. 628 (1929) (notice by implication where the bank knew of deposit of partnership funds to a personal account).

${ }^{46} \mathrm{It}$ is possible that in entering his late stop order the drawer might provide the bank with such detailed information that the attempted stop order might be treated as adequate notice of an adverse claim. However, a stop order, to be sufficient in form, need only describe the check with "reasonable accuracy." Mitchell v. Security Bank, 85 N.Y. Misc. 360, 363, 147 N.Y. Supp. 470, 471 (S. Ct., 1914). There is no requirement that the reason for the stop order be given. The check number, if given, must be accurate. John H. Mahon Co. v. Huntington Nat. Bank of Columbus, 62 Ohio App. 261, 23 N.E. 2d 638 (1939). The date must be specified accurately. Mitchell v. Security Bank, supra. And probably also the face amount and payee must be shown. A. Sidney Davison Coal Co. v. Nat. Park Bank, 201 App. Div. 309, 194 N.Y. Supp. 220 (1st Dep't, 1922); Levine v. Bank of United States, 132 N.X. Misc. 130, 229 N.Y. Supp. 108 (N.Y. Munic. Ct., 1928). 
with the banks' growing insistance on detailed information in a stop order form, it may be that they are inviting adverse claim duties in seeking to discourage stop orders.

The bank's slander of credit dilemma has doubtless placed great pressures on courts to reduce the period of protection the bank must extend, increase the standards of adequacy of notice, and limit the circumstances under which adverse claims may be valid. These limitations may have been pushed to the point where the protection seemingly provided the troubled drawer by the adverse claim duty is almost illusory.

After a check has been paid, the protection accorded the drawer, of course, cannot be of the absolute nature of that provided by the stop payment right, for the policy supporting protection to drawers then conflicts with other values-the importance of assurance to the depositor that his account will not be frivolously "frozen," and to the bank that it will not face double liability. The courts have in some degree succeeded in achieving a balancing of values in the more limited protection extended drawers in the adverse claim cases. But the balance has been got by defining narrowly the fact situations which give rise to the adverse claim duty in commercial situations, rather than by reducing the degree of conflict of interests, and attendant risks to banks and depositors, by making the rules clear and their applications predictable.

\section{III}

The second branch of the problem concerns the protection afforded the drawer after his check has been certified. ${ }^{47}$,

The policy considerations favoring protection are much the same as with uncertified checks. ${ }^{48}$ There is no a priori reason to assume that certified checks are obtained through fraudulent efforts or in some way go astray less often than the ordinary variety. However, the special nature of certified checks raises problems not encountered with regard to ordinary checks. Although certification is often equated to payment in its effect in terminating the drawer's stop payment right, the two acts are quite different in every other respect. The certified check remains in circulation, primary responsibility for its payment having been shifted from the drawer to the certifying bank. ${ }^{49}$ Upon certification the bank does debit the drawer's account, just as upon payment. The credit balancing this debit, however, is not to the account of another depositor, as it may be when the check is paid, but to "certified checks outstanding," a different type of

47 "[A]fter the bank has paid, or placed itself under an obligation, or has incurred a liability, to comply with the order, the drawer's power to revoke is at an end." 5A Michie, Banks and Banking $\$ 193$ (rev. ed., 1950). The rule is repeated in virtually all stop payment cases, despite its logical circularity: the drawer's power to revoke depends on the bank's obligation to pay - whether the bank is obligated to pay depends on whether the courts recognize the drawer's power to revoke.

1820 Univ. Chi. L. Rev., op. cit. supra note 1, at 668.

${ }^{9}$ NIL $\$$ 188-89. 
liability account. Thus, honoring a drawer's stop order after certification while the certified check remains outstanding does not present the risk of slander of another depositor's credit which may be involved in similarly treating a stop order after payment. ${ }^{50}$

On the other hand, certification is obtained to increase the commercial acceptability and liquidity of paper, and these attributes are impaired in some degree by the stop payment or adverse claim risk..$^{61}$

Perhaps because of the absence of slander of credit difficulties, some courts and legal writers have come to refer to the possibility of "stopping payment of a certified check" in certain circumstances, ${ }^{52}$ although never referring to the possibility of "stopping payment of a paid check." In fact the cases more nearly indicate that after certification, just as after payment, the protection afforded the drawer is limited to that arising from the adverse claim rules. To speak of a right of "stopping payment" of certified checks is clearly a confusion.

The typical certified check case arises in a suit brought by the holder against the certifying bank which, because of notice of the drawer's adverse claim, or stop order, has refused payment. The question, exactly as in the adverse claim cases, is whether the existence of the claim or stop order provides the bank a good defense. The bank would clearly be happy to pay the fund to the holder and be done with it, but dares not for fear of liability to its claimant-depositor. The defense is found good, or interpleader is granted, in those cases where the underlying transaction is "void" or "voidable," most often because of fraud..83 In the leading case of Sutter v. Security Trust Company, ${ }^{54}$ a widely cited dictum approved as adequate bases for interpleader, adverse claims based on "fraud, duress, or force and fear, or other unlawful means, or for an illegal consideration." ${ }^{155}$ In Bathgate v. Exchange Bank, ${ }^{56}$ a suit by the payee against the bank after refusal of payment, the Missouri court allowed the bank to interplead the drawer in a case where fraud was the basis for his adverse claim, and where "it does not

${ }^{50}$ See page 140 supra.

${ }^{51} \mathrm{On}$ the nature and history of the certified check, consult Steffen and Starr, A Blue Print for the Certified Check, 13 N.C.L. Rev. 450 (1935).

${ }^{62}$ Consult, e.g., the discussion and review of cases in Roberts and Morris, Effect of a Stop Payment Order on a Certified Check, 5 Wyo. L.J. 170 (1951). See also Brady, The Law of Bank Checks $\$ 247$ (2d ed., 1926): "It is generally held that payment of a check cannot be stopped after the check has been certified."

${ }^{53}$ This is not inconsistent with the general rule that stop payment is not available as to a certified check, if the stop payment rules applicable to ordinary checks are the subject of the reference. The adequate defenses are those which would be available in any adverse claim situation. The argument will be further developed that "stop payment" as to certified checks is a misnomer referring to the adverse claim protection available after certification as after payment.

54 96 N.J. Eq. 644, 126 Att. 435 (Ct. of E. \& A., 1924), aff'g 95 N.J. Eq. 44, 122 Atl. 381 (Chancery, 1923), noted in 35 A.L.R. 942 (1925); 25 Mich. L. Rev. 367 (1924); 72 U. Pa. L. Rev. 318 (1924).

${ }^{55}$ Ibid., at 648,and 437.

ss 199 Mo. App. 583, 205 S.W. 875 (1918). 
know and cannot ascertain, except at its peril, whether said check has been legally delivered, and whether plaintiff is the lawful holder thereof, or not." "67 The court further pointed out: "In the case of an uncertified check, the bank, after receiving notice of a dispute as to the holder's right to its possession, cannot pay it except at its peril; and the certification thereof at the drawer's request does not lessen, in any degree, its obligation to pay it only in case the check was in fact rightfully delivered; nor does such certification add an unconditional duty to pay said check to plaintiff regardless of whether it had been rightfully delivered to him." "58 But where only failure of consideration appeared to be present, the highest Kansas court, in a suit by the holder, ${ }^{59}$ denied a request for interpleader, and the bank was ordered to pay the fund to the holder. Neither is it enough as a defense that the "stop order" was given because the drawer, a bank, having discovered that the payee bank has become insolvent would have the right of set-off against the payee except for the certification. ${ }^{60}$

Thus, whether the drawer succeeds is made to depend on the nature of the transaction underlying the issue of the check, ${ }^{61}$ the acceptable defenses being identical with those which give rise to a valid adverse claim in the "payment" cases; ${ }^{62}$ such determinations are never in issue in ordinary stop payment cases, the drawer's right of revocation being absolute. Particularly informative is the Barnard case, ${ }^{63}$ discussed in part earlier ${ }^{64}$ in which the court indicated that a certified check drawn by a depositor payable to himself should be subject to adverse claim treatment in the same manner as funds in the depositor's account.

Another demonstration that so-called "stop payment" after certification is more properly considered as an adverse claim than as ordinary stop payment, is the differing treatment of the instrument in the hands of a holder in due course. The rule as to ordinary checks is that a bank has no more authority, after a stop order, to pay a bona fide purchaser for value than the payee or any other holder. ${ }^{65}$

$$
{ }^{57} \text { Tbid., at } 587 \text { and } 877 .
$$

59 McAdoo, Director General of Railroads v. Farmers' State Bank of Zenda (Smith, Intervenor), 106 Kan. 662, 189 Pac. 155 (1920).

${ }^{60}$ Carnegie Trust Co. v. First Nat. Bank, 213 N.Y. 301, 107 N.E. 693 (1915).

${ }^{61}$ See, further, Welch v. Bank of the Manhattan Co., 264 App. Div. 906, 35 N.Y.S. 2d 894 (2d Dep't, 1942), where interpleader was allowed on what appears no more than failure of consideration; however, the court designates it as "fraud and waste." Ibid., at 907 and 895. The rule of Blake v. Hamilton Dime Savings Bank, 79 Ohio St.189, 87 N.E. 73 (1908), would clearly refuse to permit stop payment after certification, and the case may even be read to go so far as to prohibit adverse claims. But, in a dictum, the court says, "[E]ven if the certified check were not treated as money but as property ... Blake could neither recover it nor defend against payment of a suit upon it, in the absence of a showing that he had repudiated the trade and had tendered the horse to Werbel, which was not done in this case. ..." Ibid., at 202 and 76. The notice of adverse claim was not valid, there being no recital of acts of rescission, so the adverse claim issue was not presented.

See page 141 supra.

${ }^{63}$ Barnard v. First Nat. Bank of Newpoint, 61 Ind. App. 634, 111 N.E. 451 (1916).

${ }^{64}$ See page 138 supra.

${ }^{65} 20$ Univ. Chi. L. Rev., op. cit. supra note 1 , at 672 n. 21. 
Yet a holder in due course of a certified check cannot successfully be refused payment, ${ }^{66}$ just as no adverse claim can be effective as against a bona fide purchaser, but only against the proceeds of the sale.

Thus the recent certified check "stop payment" doctrine is similar in little more than name to the traditional stop payment rules; the protection afforded a drawer after his check has been certified is more properly found in ordinary applications of adverse claim principles. Confusion on this matter by a few courts is responsible for the current unsatisfactory state of case law on the certified check problem.

The New Jersey courts are most responsible for the present difficulties. ${ }^{67}$ In the Sutter case $^{68}$ the court held as controlling a distinction between checks certified at the instance of the drawer and those certified for the payee or other holder ${ }^{69}$ Where the bank had withheld payment to the payee after notice from the drawer, the defenses discussed above, it was said, would be sufficient in cases where the check was certified at the instance of the drawer. "Stop payment" would not, however, be available where certification was procured by the holder. The justification for the distinction was found in Section 188 of the NIL: "Where the holder of a check procures it to be accepted or certified the drawer and all indorsers are discharged from liability thereon." The corollary is that where the drawer secures the certification, he remains secondarily liable. Thus, relying on a premise which is not made explicit, "stop payment" is said to be available when the drawer procures the certification, otherwise not.

But Section 188 codified a common law rule in a line of cases in which the question was whether certification operates to discharge the drawer from liability on his instrument in case the certifying bank fails before the check is paid. ${ }^{70}$ So the hidden premise must link bank failures to a right to stop payment, and is indeed tenuous.

It has been further argued that the holder of a check is entitled to present it only for payment and if, instead of demanding payment, the holder secures the bank's certification, he enters into a new contract with the drawee bank which was not within the contemplation of the drawer. ${ }^{71}$ But this is logic, too, which makes sense only as to whether or not the drawer is discharged, not as to whether he can "stop payment" by entering an adverse claim. On the contrary, it is more

${ }^{\infty}$ See, e.g., Sutter v. Security Trust Co., 96 N.J. Eq. 644, 647, 126 Atl. 435, 437 (Ct. of E. \&. A., 1924): "Upon this all the authorities are in agreement."

${ }^{67}$ Consult Brady, The Law of Bank Checks $\$ 247$, at 404 (2d ed., 1926).

${ }^{68}$ Sutter v. Security Trust Co., 96 N.J. Eq. 644, 647, 126 Atl. 435, 637 (Ct. of E. \& A., 1924).

${ }^{60}$ The existence of a distinction was first asserted in Times Square Automobile Co. v. Rutherford Nat. Bank, 77 N.J.L. 649, 73 Atl. 479 (1909), a case involving a check certified at the request of the holder, but was not there decided, being immaterial to the holding.

${ }^{70}$ Consult Brady, The Law of Bank Checks $\$ 237$, at 388 (2d ed., 1926), and cases there cited.

711 Paton, Dig. Leg. Ops. 821 (1940). 
reasonable to argue, in the adverse claim-stop payment situation, that a defrauding payee who secures certification without the drawer's knowledge should be more vulnerable, not less, than one for whom the drawer takes the initiative.

Even more persuasive, however, is the fact that the distinction is misleading. The typical businessman faced with a certified check is unlikely to examine the check or to inquire to find, as a guide to whether its payment is certain, who had it certified. Under these circumstances, Section 188 should be read in a restrictive way-limited to its original bank failure context-rather than expanded in effect. It is probable that only because the real nature of so-called "stop payment" of certified checks has been lost sight of by some courts, that this confusing and inutile statutory misinterpretation has gained some currency. ${ }^{72} \mathrm{It}$ is clear that the limited protection to the drawer given by the adverse claim principles does not depend on who secured certification, so long as the ownership of the funds in the certifying bank is in real dispute.

A case in which the true nature of the adverse claim-stop payment situation as to certification is clearly stated is Greenberg 0 . World Exchange Bank, ${ }^{73}$ involving a certified note. There the court pointed out that a certifying bank paying out money on an instrument after notice that the funds did not, in fact, belong to the holder, would be making a wrongful payment, because such an act, if the reason asserted for stopping payment were sufficient, would be "payment to a constructive trustee after notice of the trust." ${ }^{4}$ The Greenberg rule properly allows the defense of fraud regardless of who obtained certification, if proper notice is given that the drawer had taken steps to rescind the voidable sale in which the instrument had been given. Because this was not shown in the case, however, the bank was directed to make payment to the holder.

But for a growing number of state statutes ${ }^{75}$ which prohibit stop payment of certified checks, and a similar provision in the proposed Uniform Commercial Code, ${ }^{76}$ this confusion as to the distinction between stop payment and adverse

72 The currency is not wide. Since the Sutter decision, the New Jersey courts have been controlled by a statutory provision that "No banking institution shall stop payment of any check certifed by it." N.J. Stat. Ann. (perm. ed.) $\$ 17: 9 A-225(A)$. A similar statute is now in effect in New York. N.Y. Negotiable Instruments Law (McKinney, 1943) § 325, amended by N.Y.L. (1944) c. 537. But the distinction appears to be operative in Indiana, Nardine v. Kraft Cheese Co., 114 Ind. App. 399, 52 N.E. 2d 634 (1944); and Missouri, Bathgate v. Exchange Bank, 199 Mo. App. 583, 205 S.W. 875 (1914). But cf. Kellogg v. Citizens' Bank of Ava, $176 \mathrm{Mo}$. App. 288, 162 S.W. 643 (1914). The distinction has not been made determining as to "stop payment," or adverse claims, cases arising in Arkansas, Merchants' \& Planters' Bank v. New First Nat. Bank, 116 Ark. 1, 170 S.W. 852 (1914); Florida, Florida Light \& Power Co.v. Tomasello, 103 Fla. 1076, 139 So. 140 (1932); Kansas, McAdoo v. Farmers'State Bank, 106 Kan. 662, 189 Pac. 155 (1920); or Ohio, Blake v. Hamilton Dime Savings Bank, 79 Ohio St. 189, 87 N.E. 73 (1908). The majority of jurisdictions appear not to have been called upon to decide the question.

${ }^{73} 237$ N.Y. Supp. 200 (S. Ct., 1929).

"Ibid., at 203.

${ }^{75}$ See note 72 supra.

${ }^{76}$ American Law Institute, National Conference of Commissioners on Uniform State Law, Uniform Commercial Code: Official Draft (text and comments ed., 1952) $\$ \S 3-410,4-303$. And see $\$ 4-403$, comment 5 . 
claim might be left respectfully to lie as a minor episode in the archives of banking law.

But in the foregoing analysis, the proper interpretation of these statutes is not that they withdraw the ancient privilege of adverse claim against funds represented by certified checks, but that their effect is rather to destroy the comparatively recent "stop payment" doctrine, including the distinction of the Sutter case between treatment given when certification is obtained by a drawer and when obtained by a holder. The rights and duties following from notice to a bank of an adverse claim, which are not stop payment rights and duties at all, should not be regarded as destroyed, but as available, in those most difficult situations in which they are appropriate, to the distressed or defrauded drawer. This should mean that the drawer of a certified check should be entitled to the protection, in those cases where a valid adverse claim can be shown, of having the bank preserve the funds intact by withholding payment until the drawer can reasonably undertake legal action against the payee. This should be the result without regard to which party procured the certification.

\section{IV}

It has been seen that the applicability of the adverse claim rules to fact situations involving checks after payment or certification has been narrowly limited by the courts-in states following the Sulter distinction, more narrowly after certification than after payment.

It is not at all clear, however, that the best way in which to take care of the conflict with other values which arises after a check is paid or certified-and which is not present in ordinary stop payment-is by arbitrarily refusing protection, case by case, by such technical devices as finding "notice" formally inadequate or by overlooking fraud because the mechanics of recision have not been undertaken. It would seem more desirable to extend the protection to include all cases of real difficulty of which the bank is properly informed, while minimizing the real risks and conflicts of interest among the parties by statutory provisions making more precise the extent of the banks' duty, and providing the bank with protection against loss while carrying out its obligations.

The final draft of the Uniform Commercial Code takes no major steps in this direction. ${ }^{77}$ As recently as the May, 1949 Draft, its Reporters had included a section which would have eliminated the adverse claim duty altogether except after specified legal process. ${ }^{78}$ This proposal, which would have eliminated the

77 The Official (final) draft does take one step toward reducing the painfulness of the bank's dilemma-it removes the common law presumption that the dishonor of the check of a merchant reflects on his credit and thus entitles him to "substantial" damages without proof of actual injury. See note 34 supra, and op. cit. supra note 76, at $\$ 4-402$. But it will throw no light on the major questions of adequacy of notice, "reasonable" time, or what constitutes sufficient basis for a valid adverse claim.

78 "Where a person other than the customer makes a claim or serves legal process upon a bank with respect to the customer's account therein, neither the claim nor the process affects the bank or constitutes notice to it unless (a) the process issues in an action in which the customer is designated as a party by the name in which the account stands; or (b) the claimant 
technical difficulties by ignoring the fundamental problem, fortunately no longer appears. Still, Article 3 of the Code would be considerably stronger if its drafters had succeeded in the not too difficult task of defining rules which would offer needed protection, in the form of certainty, both to the bank and to legitimate adverse claimants.

is appointed by a court of competent jurisdiction to succeed to the customer's rights in the account." American Law Institute, National Conference of Commissioners on Uniform State Law, May 1949 Draft Uniform Commercial Code \& 3-640 (May, 1949).

\section{JUDICIAL INNOVATIONS IN THE NEW YORK ARBITRATION LAW}

The New York arbitration law appears to be undergoing gradual revision by judicial interpretation. Recent New York law reports show a trend toward narrowing the arbitrator's function by enlarging the jurisdiction of the courts in several areas of arbitration law. Thus, in the field of labor arbitration the courts have for some time construed their power to determine whether the parties have agreed to arbitrate to include the power to determine whether there is an arbitrable dispute. In the recent case of Alpert v. Admiration Knitzear Co. ${ }^{1}$ this rule was carried over into the field of commercial arbitration as well.

In the Alpert case the contract of sale contained the following provision: "[ $\mathrm{I} f \mathrm{f}$ at any time, in the sole opinion of the Seller, the financial responsibility of the Purchaser shall become impaired or unsatisfactory to the Seller cash payments in advance of delivery may be required." Failure of the buyer to pay any amount due gave the seller the right to terminate the contract. When the purchaser failed to comply with a demand for advance payment under this clause, the seller terminated. The buyer moved under $\S 1450$ of the New York arbitration statute $^{3}$ to compel arbitration according to an arbitration clause in the contract. The purchaser claimed that in commercial understanding the seller's right to demand advance payment was conditioned upon reasonable apprehension as to the purchaser's financial responsibility. While the arbitration clause provided that "[a]ny complaint, controversy or question which may arise with respect to this contract that cannot be settled by the parties thereto, shall be referred to arbitration. ..."4 the court said it was plain that there could be no dispute as to the meaning of the acceleration clause; according to the plain language of the contract, the seller had an unconditional right to demand advance payment and non-compliance with such demand by the buyer gave the seller the right to terminate the contract. The court held that as there was nothing for the arbitrators to decide, the motion should be denied.

2304 N.Y. 1, 105 N.E. 2d 561 (1952). 2 Ibid., at 4 and 562.

${ }^{3}$ N.Y. Civ. Practice Act (Thompson, 1939) $\$ \$ 1448-69$.

4304 N.Y. 1, 5, 105 N.E. 2d 561, 563 (1952). 